Edyta Januszewska

[Warszawa]

Izabela Lewandowska

[Olsztyn]

\title{
Seminarium biograficzne \\ w naukach społecznych, czyli jak rozmawiać o relacjach ustnych w różnych kontekstach
}

Wrocławski Rocznik Historii Mówionej Rocznik III, 2013 ISSN 2084-0578

W Instytucie Socjologii na Wydziale Ekonomiczno-Socjologicznym Uniwersytetu Łódzkiego prof. Kaja Kaźmierska cyklicznie organizuje seminaria biograficzne. Te interdyscyplinarne spotkania pozwalają zarówno młodym, jak i doświadczonym już badaczom wymienić się doświadczeniami w zbieraniu relacji ustnych oraz $\mathrm{w}$ analizie tekstu powstałego $\mathrm{w}$ wyniku transkrypcji. Spotkania biograficzne koncentrują się wokół badań jakościowych, które dopiero na początku XXI w. doczekały się w Polsce literatury metodologicznej. Natomiast metodologia polskich badań nad historią mówioną (oral history) ciągle się tworzy. Oczywiście istnieje obszerna literatura angielska i amerykańska na temat badań jakościowych i oral history, ale zauważa się konieczność jej przystosowania do polskich warunków badawczych.

Na seminarium spotykają się badacze reprezentujący różne dyscypliny: socjologię, etnologię, antropologię, historię, pedagogikę, psychologię, geografię, a nawet anglistykę. Instytucjonalnie reprezentowany jest Instytut Socjologii UŁ (jako organizator), Wydział Nauk o Wychowaniu UŁ, Wydział Nauk Geograficznych UŁ, Instytut Etnologii i Antropologii Kultury Uniwersytetu Warszawskiego, Instytut Filozofii i Socjologii Polskiej Akademii Nauk, Akademia Pedagogiki Specjalnej im. Marii Grzegorzewskiej 
w Warszawie, Instytut Historii i Stosunków Międzynarodowych Uniwersytetu Warmińsko-Mazurskiego w Olsztynie, Ośrodek „Karta” w Warszawie i Wyższa Szkoła Pedagogiczna w Skierniewicach.

Spotkania odbywają się od listopada 2011 r. i do tej pory analizowano na nich wywiady dotyczące: doświadczeń kulturowych i przemian tożsamościowych studentów polskiego pochodzenia z krajów byłego ZSRR w Polsce; tożsamości narodowej przedstawicieli białoruskiej inteligencji na Białorusi; losów wychowanków domu dziecka; pracy Polaków za granicą; pracy osób w charakterze pomocy domowej i opieki nad członkami rodziny w powojennej Polsce (1945-2010); pracy w fabryce czekolady Wedla; sponsoringu; losów życiowych osób skazanych, osadzonych w zakładzie karnym; biografii osób transseksualnych oraz karier zawodowych wysokiej klasy menedżerów.

Przykładowo, omówimy szerzej jeden $\mathrm{z}$ analizowanych tematów. 11 stycznia i 1 lutego 2013 r. odbyły się dwa spotkania poświęcone dwuletniemu projektowi międzynarodowemu pt. Doświadczenie biograficzne w PRL i NRD oraz jego przepracowanie w pokoleniu 1945-1955. Porównanie dwóch perspektyw. W pierwszej części seminarium uczestnicy projektu omówili założenia projektu: jest on obecnie w trakcie realizacji - wywiady są zbierane i transkrybowane, a następnie przeprowadzane są wspólne analizy. Po stronie niemieckiej projektowi partneruje Uniwersytet w Magdeburgu, reprezentowany przez prof. Fritza Schütze, po stronie polskiej uczestniczy w nim Katedra Socjologii Kultury Uniwersytetu Łódzkiego, pod kierownictwem prof. Kai Kaźmierskiej oraz Ośrodek Karta w Warszawie. Projekt jest finansowany przez Polsko-Niemiecką Fundację na rzecz Nauki. Zagraniczni specjaliści pochodzą z Niemiec Zachodnich, ale w obszarze ich zainteresowań badawczych znajduje się teren NRD. Z badań już dzisiaj wyłania się wiele ciekawych kontrastów między PRL a NRD, np. to, że polscy chłopi mają duże poczucie identyfikacji narodowej, przede wszystkim związanej z ojcowizną i z religią. Relacje pokazują pewną wspólnotę ich losów, co dla partnerów z Europy Zachodniej jest abstrakcyjne, tak samo jak pojęcie etosu chłopa. Projekt jest inspirujący poznawczo również dla samych, realizujących go badaczy, którzy uczą się od siebie nawzajem. Każda ze stron ma zebrać 40 wywiadów, a połowa z nich ma być przetłumaczona na język angielski. W tym języku ma też powstać monografia kończąca projekt. Do badań wybrano kilka grup społecznych: 1) robotników i rolników, jako grupy społecznie faworyzowane przez ówczesny system; 2) ówczesnych biznesmenów, tzw. prywatną inicjatywę; 3) przedstawicieli wolnych zawodów i naukowców, reprezentantów lokalnej władzy; 4) ówczesnych studentów, 
którzy brali udział w strajku na Uniwersytecie Łódzkim w 1981 r.; 5) przedstawicieli opozycji i duchowieństwa na szczeblu lokalnym; 6) nauczycieli; 7) tzw. zwykłych ludzi, np. sprzedawczyń w sklepie, fryzjerek, włókniarek. Osoby badane po stronie polskiej pochodzą z kilku regionów: Mazowsza, Wielkopolski, Dolnego Śląska i Pomorza Zachodniego.

Celem projektu jest uchwycenie zróżnicowania pamięci i wielości przekazów, a także wypracowanie nowego języka opisu okresu PRL-u, gdyż w pracach dotyczących tej tematyki często do opisu rzeczywistości stosuje się stereotypy. Trudno jest znaleźć „poprawny” język opisu związany z doświadczeniem PRL. Istnieją obecnie dwie narracje: jedna, polityczno-historyczna, opierająca się na przełomach z lat 1956, 1968, 1970, 1981 itd.; druga, oparta na prześmiewaniu PRL-u (dobrymi tego przykładami są np. filmy Stanisława Barei: „Miś”, „Alternatywy 4”, „Poszukiwany, poszukiwana” itp.). W odniesieniu do pamięci PRL-u nie ma monolitycznej narracji, ale wielogłosy. Dzisiaj nie wiemy, jak opisać doświadczenie człowieka, który zapisuje się do partii, a chodzi do kościoła, wewnętrznie popiera Solidarność, ale oficjalnie jest jej obojętny lub nieprzychylny. Język indywidualnego opisu wywodzi się z tradycji rodzinnych. Stąd też, jeżeli jednostce było dobrze w czasach PRL, to inaczej będzie ją przedstawiała w swej relacji, niż ci, którzy byli represjonowani lub żyli na uboczu i w biedzie. Trzeba więc zerwać z tradycyjnym postrzeganiem przeszłości i zacząć wyrażać protest wobec opisów oraz wyborów dokonywanych przez rodziców.

Podczas drugiej części styczniowego seminarium w Łodzi analizowano dwa wywiady, których transkrypcje zostały przekazane uczestnikom seminarium kilka tygodni wcześniej. Zgodnie z etyką badań osoby, z którymi przeprowadzono wywiady, podpisały zgodę na archiwizację i wykorzystanie relacji do badań naukowych oraz otrzymały kopie nagrań.

Najpierw przeprowadzający wywiad (dr Piotr Filipkowski z „Karty”) omówił sytuację rodziny i okoliczności powstania wywiadu. Jego rozmówcy byli polskimi rolnikami, w podobnym wieku, którzy żyli w okresie PRL i do dzisiaj prowadzą gospodarstwo. Cechuje ich ciągłość przywiązania do ziemi, sakralizacja ojcowizny, różni je miejsce zamieszkania, sposób nazywania swojej pracy, podejścia do niej (na Mazowszu rozmówca uprawia ziemię końmi, w Wielkopolsce funkcjonuje wielkie przedsiębiorstwo rolne, na początku 5 ha, a dzisiaj 200 ha).

Każdy z uczestników seminarium mógł wypowiedzieć się na temat przeczytanych wywiadów. Podczas dwóch spotkań wywiady były analizowane na tle historycznym, co pokazało wyraźne różnice w interpretacji 
tego materiału przez pedagogów, socjologów i historyków. Pojawiły się uwagi co do metodologii badań, zapisu relacji, uwidocznienia emocji poprzez zapisywanie ich w nawiasach kwadratowych. Socjologowie doszukiwali się kontekstów, podtekstów, analizowali wnętrze człowieka. Historycy traktowali rozmówców jako „świadków historii”. Inaczej niż w badaniach oral history imiona rozmówców zostały zmienione przed udostępnieniem relacji do analizy, socjologowie zmienili także nazwę miejscowości, która była potem trudna do ustalenia. W badaniach oral history rozmówca jest świadkiem historii, jest osobą sygnowaną prawdziwym imieniem i nazwiskiem, opowiada o miejscach, które są rozpoznawalne.

Na kolejnym spotkaniu, 1 lutego 2013 r., analizowane były dwa kolejne wywiady z rolnikami. Jeden z uczestników seminarium dokonał ciekawego porównania bohatera jednego z wywiadów z postacią historyczną: Janem Słomką, żyjącym na przełomie XIX i XX w. chłopskim działaczem społecznym i gospodarczym w Galicji, co stworzyło interesującą perspektywę interpretacyjną. Podczas dyskusji pojawiały się także głosy odnoszące się do subiektywności ocen badaczy i trudności w ich uogólnianiu. Interesujący jest fakt, iż pomimo młodego wieku uczestników seminarium, w czasie dyskusji większość odwoływała się do własnych doświadczeń lub doświadczeń członków rodziny z czasów PRL-u. Zwrócono też uwagę na kilka zagadnień metodologicznych i interpretacyjnych, np. kwestię anonimizacji tożsamości narratora, sposób interpretacji rzeczywistości przez respondenta czy niekonsekwencje faktograficzne w narracjach.

Spotkania seminaryjne pokazują, że nawet na podstawie analizy tych samych źródeł badacze dochodzą do różnych wniosków. Dlatego tak ważny jest pewien stopień ujednolicenia i wypracowania standardów, szczególnie gdy chodzi o projekty, w których analizuje się wiele biografii.

Taką standaryzację przedstawiła na zakończenie spotkania z 1 lutego 2013 r. dr Katarzyna Waniek z Katedry Socjologii Kultury (jedna z organizatorek seminarium). Grupa projektowa, na podstawie przeprowadzonych wcześniej wywiadów, wypracowała bowiem kategorie, do których należą m.in.:

1) kategoria ponadczasowa - zwykły pragmatyzm i mądrość chłopska

a) podkategorie:

- chęć posiadania nie tylko dóbr materialnych, lecz także wykształcenia, które jest uważane przez chłopów za dobro materialne,

- religijność chłopska,

- przyroda, która jest traktowana przez rolników jako narzędzie ich pracy, 
- chłopski etos, który przejawia się m.in. przez szacunek do instytucji (harcerstwo, wojsko)

- w ramach tych podkategorii udało się wyodrębnić takie cechy chłopa, jak: konkretność, zdecydowanie i dążenie do wyznaczonych celów;

2) kategoria: sposób zmagania się z rzeczywistością;

3) kategoria: reakcje na przeszłość, czyli różne sposoby opowiadania o PRL przez różnych narratorów;

4) kategoria: różne doświadczenia trajektorii;

5) kategoria: napięcie między życiem publicznym i prywatnym;

6) kategoria: sposób podchodzenia narratorów do zmiany społecznej pod koniec lat 8o. XX w.;

7) kategoria: różnice i podobieństwa ekonomiczne w PRL i NRD.

Cykliczne seminaria biograficzne, prowadzone w Instytucie Socjologii przez prof. Kaję Kaźmierską, stały się platformą wymiany doświadczeń badaczy $\mathrm{z}$ wielu środowisk w obszarze analizy wywiadów narracyjnych. Seminaria te doskonale wpisują się w nurt metodologii badań jakościowych i biograficznych oraz wypełniają lukę warsztatów metodologicznych na mapie polskich ośrodków naukowych zajmujących się oral history i badaniami jakościowymi.

Informacje o kolejnych seminariach można uzyskać, pisząc na adres: badania.biograficzne@gmail.com. 